\title{
Purwarupa Portable Global Positioning System
}

\author{
Haniah*1, Agfianto Eko Putra $^{2}$ \\ ${ }^{1}$ Program Studi Elektronika dan Instrumentasi, FMIPA UGM, Yogyakarta \\ ${ }^{2}$ Jurusan Ilmu Komputer dan Elektronika, FMIPA UGM, Yogyakarta \\ e-mail: *1hanilikebunny@yahoo.com, ${ }^{2}$ agfi68@ugm.accom
}

\begin{abstract}
Abstrak
Telah dibuat sebuah sistem GPS portable menggunakan receiver GPS serta tampilan LCD 128X64. Sistem ini dapat membantu pengguna untuk mengetahui posisi mereka berada agar tidak tersesat. Sistem ini menampilkan data latitude, longitude, kecepatan dan waktu yang ditampilkan pada LCD 128X64. Sehingga pengguna bisa mengetahui posisi mereka dengan melihat posisi garis lintang dan garis bujur. Sistem ini dibuat dengan menggunakan mikrokontroler ATmega32 sebagai pemroses, GPS receiver Polstar PMB-688 untuk menerima data posisi dari satelit dan LCD $128 X 64$ sebagai penampil. Sistem yang dibuat telah mampu menampilkan posisi garis lintang, garis bujur dan kecepatan secara akurat. Deviasi rata-rata untuk GPS portabel dibanding dengan GPS garmin adalah 1,753449 $m \pm 0,113532 \mathrm{~m}$ sedangkan deviasi rata-rata untuk kecepatan adalah $0,441 \mathrm{~km} / \mathrm{j} \pm 0,247 \mathrm{~km} / \mathrm{j}$.
\end{abstract}

Kata kunci-GPS, Posisi, Polstar PMB-688, Atmega32, Mikrokontroler.

\begin{abstract}
Has created a portable GPS system uses a GPS receiver as well as an LCD display 128X64. This system can help users to identify where they are located so as not to get lost. This system displays the latitude, longitude, speed and time are displayed on the LCD 128X64. So users can know their position by looking at the position of latitude and longitude. This system using microcontroller ATmega32 as processor, GPS receiver Polstar PMB-688 to receive position data from satellites and LCD $128 X 64$ as a viewer. The system is already capable of showing the position of the latitude, longitude and speed accurately. Average deviation for GPS portable than static point is $1.753449 \mathrm{~m} \pm 0.113532 \mathrm{~m}$ while the average deviation for speed is $0.441000 \mathrm{kmh} \pm 0.247000 \mathrm{kmh}$.
\end{abstract}

Keywords-GPS, Position, Polstar PMB-688, Atmega32, Mikrocontroller.

\section{PENDAHULUAN}

$\mathrm{G}$ PS pada awalnya digunakan untuk keperluan militer sebagai alat navigasi pasukan ataupun pesawat tempur. Setelah beberapa tahun, GPS bisa digunakan secara bebas untuk navigasi bagi masyarakat dunia. Dengan GPS manusia dapat mengetahui posisi pengguna berada. GPS ini bisa memberikan informasi secara akurat dimana pengguna berada karena GPS ini menerima sinyal dari satelit. Informasi yang diberikan oleh GPS berupa posisi garis lintang dan garis bujur serta kecepatan. Tujuan dari penelitian ini adalah membuat sistem GPS portable dengan kontroler ATmega32 dan penampil graphic LCD 128x64 yang nantinya akan menampilkan data berupa waktu, tanggal, garis bujur, garis lintang, dan kecepatan. Lalu dilakukan kalibrasi dengan membandingkan datanya dengan GPS Garmin 60Cx.

Sebuah antarmuka GPS menggunakan Mikrokontroler menggunakan modul GPS Motorola sebagai receivernya digunakan sebagai tesis berjudul "Interfacing a GPS to an LCD 
using a Microcontroller". Sebagai pusat pengendali dia menggunakan mikrokontroler atmel 89C55 serta penampil berupa graphic LCD. Data yang diterima oleh receiver kemudian diolah pada pengendali kemudian ditampilkan secara paralel melalui graphic LCD. Bahasa yang digunakan adalah bahasa $\mathrm{C}++$.

Mahasiswa Universitas Negeri Yogyakarta dalam penelitian yang berjudul "Pembacaan Posisi Koordinat dengan Global Positioning System (GPS) sebagai Pengendali Palang Pintu Rel Kereta Api secara Otomatis" juga menggunakan GPS sebagai penentu koordinat. Sistem ini menggunakan modul GPS tipe TYCO yang mempunyai 15 pin, sudah dilengkapi dengan kaki antena untuk penangkap sinyal dan juga kaki untuk baterai cadangan. Pengendali yang digunakan adalah ATmega8535. Informasi yang diperoleh dari GPS receiver akan ditampilkan melalui SMS yang kemudian akan menggerakan palang pintu kereta.

Penelitian ini merupakan pengembangan dari beberapa penelitian yang ada pada saat ini. Pada tugas akhir yang dilakukan oleh mahasiswi Politeknik Universitas Andalas Padang dengan judul "Penentuan Titik Koordinat GPS dengan Menggunakan Mikrokontroler". Sistem ini menggunakan modul GPS tipe WD-G-ZX4120 yang mempunyai 19 pin. Pengendali yang digunakan adalah AT89S51. Informasi yang diambil dari GPS menggunakan GPGGA. Lalu nantinya akan ditampilkan secara langsung semua data pada LCD dot matrix 16x2.

\section{METODE PENELITIAN}

Global positioning System (GPS) adalah sistem radio navigasi dan penentuan posisi dengan menggunakan satelit yang dimiliki dan dikelola oleh Departemen Pertahanan Keamanan Amerika Serikat. Sistem ini didesain untuk memberikan posisi dan kecepatan tiga dimensi dan informasi mengenai waktu secara kontinu. Sistem GPS terdiri dari 24 satelit. Konstelasi 24 satelit GPS tersebut menempati 6 orbit yang mengelilingi bumi dengan sebaran yang telah diatur sedemikian rupa sehingga mempunyai probalitas kenampakan setidaknya 4 satelit yang bergeometri baik dari setiap tempat di permukaan bumi di setiap saat [1].

\section{1 Bahan Rangakaian}

Modul-modul yang digunakan untuk merangkai GPS ini adalah:

\section{1. 1 GPS ReceiverPolstrar PMB-688}

Modul GPS receiver dari polstar ini mempunyai receiver berupa chipset SiRFstarIII yang mampu memaksimalkan kemampuan dan presisi GPS. GPS ini mampu menerima data dari 20 satelit sekaligus sehingga dapat memberikan akusisi dan reakusisi yang cepat. Akurasi untuk posisi sekitar 5 meter, akurasi untuk kecepatan sekitar $0,1 \mathrm{~m} / \mathrm{s}$ dan akurasi untuk waktu sekitar lebih kurang 1 mikrodetik [2]. Data yang dikeluarkan oleh Polstar-PMB-688 adalah NMEA0183 V2. NMEA-0183 memiliki bermacam-macam tipe kalimat, dan yang digunakan pada penelitian ini adalah Recommended Minimum Navigation Information (RMC) dengan format sebagai berikut:

\section{\$GPRMC,065102,A,0745.6301,S,11024.5308,E,000.0,066.2,030306,001.1,E*65<CR+LF>} $1[3]$.

Keterangan masing-masing bagian data NMEA-0183 tipe RMC dapat dilihat pada Tabel 
Tabel 1 Format data tipe rmc

\begin{tabular}{|l|l|l|l|}
\hline Nama & Contoh & Satuan & Keterangan \\
\hline Message ID & \$GPRMC & & RMC protokol header \\
\hline UTC Position & 065102 & & hhmmss.ss \\
\hline Status & A & & A=data valid or V=data tidak valid \\
\hline Latitude & 0745.6301 & & ddmm.mmmm \\
\hline N/S Indicator & S & & N=north or S=south \\
\hline Longitude & 11024.5308 & & dddmm. mmm \\
\hline E/W Indicator & E & & E=east or W=west \\
\hline Speed Over Ground & 000.0 & knots & \\
\hline Course Over Ground & 066.2 & degrees & \\
\hline Date & 030306 & & Ddmmyy \\
\hline Magnetic Variation & E & degrees & E=east or W=west \\
\hline Checksum & $* 65$ & & \\
\hline CR LF & & & End of message \\
\hline
\end{tabular}

\section{1. 2 Mikrokontroler ATmega32}

ATMega32 merupakan mikrokontroler keluaran ATMEL yang termasuk dalam keluarga mikrokontroler CMOS 8-bit. Mikrokontroler ini memiliki 32 register general-purpose yang membantu ALU bekerja. Selain itu mikrokontroler ini juga mempunyai timer/counter fleksibel dengan mode compare, interrupt internal dan eksternal, serial UART, Programmable Watchdog Timer, dan mode power saving serta ADC dan PWM internal. ATMega32 juga dilengkapi In-System Programmable Flash on-chip yang mengijinkan memori program untuk diprogram ulang dalam sistem menggunakan hubungan serial SPI [4].

\section{1. 3 Graphic Liquid Crystal Display LM12864FLC}

Graphic Liquid Crystal Display LM12864FLC digunakan sebagai penampil pada GPS portable. Graphic LCD ini memiliki 128x64 titik dengan tiga pilihan mode yaitu STN, Negative dan Transflectiv. LM1264FLC ini memiliki 20 pin yang 14 diantaranya dihubungkan pada mikrokontroler, sedangkan 6 kaki lainnya dipakai sebagai pengatur kontras LCD, pengatur backlight, dan sebagai penerima tegangan [5].

\section{2 Perancangan Sistem}

Rancangan sistem GPS portable ini meliputi dua bagian yaitu rancangan perangkat keras, dan rancangan perangkat lunak.

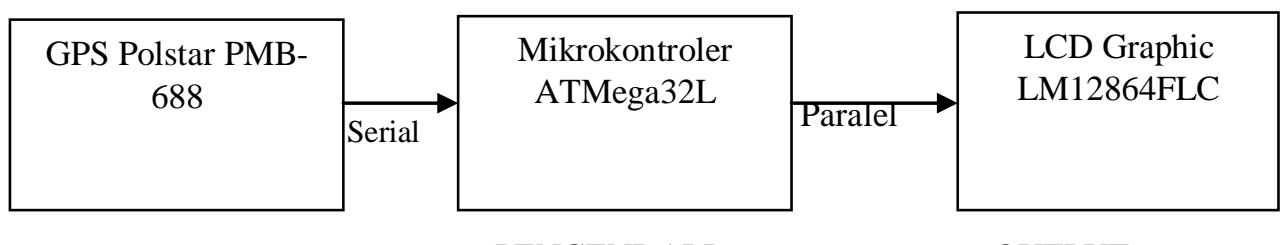

INPUT

PENGENDALI

OUTPUT

Gambar 1 Diagram blok sistem GPS portable 
Gambar 1 menunjukan diagram blok dari sistem GPS portable, dimana ATMega32L berfungsi sebagai pengendali dari sistem GPS portable ini. Mikrokontroler mendapatkan masukan dari GPS receiver yang kemudian diolah di mikrokontroler dan menampilkan hasilnya pada LCD Graphic LM12864FLC.

\section{2. 1 Perancangan Perangkat Keras}

Perancangan perangkat keras ini berupa sebuah sistem minimum untuk ATMega32L yang telah dilengkapi dengan modul GPS dan keluaran berupa LCD. Modul GPS mempunyai 4 pin, pin 1 disambungkan ke VCC, pin 2 disambungkan ke GND. Untuk keluaran dari modul GPS ini yaitu pin 3 dan pin 4 disambungkan ke pin mikrokontroler yaitu masing-masing portd. 1 dan portd.0. Pin d/I pada LCD dihubungkan pada portc.0, pin $\mathrm{r} / \mathrm{w}$ dihubungkan pada portc. 1 dan enable dihubungkan dengan portc.2. Data0 sampai data7 dihubungkan dengan porta.0 sampai porta.7 seperti terlihat pada Gambar 2.

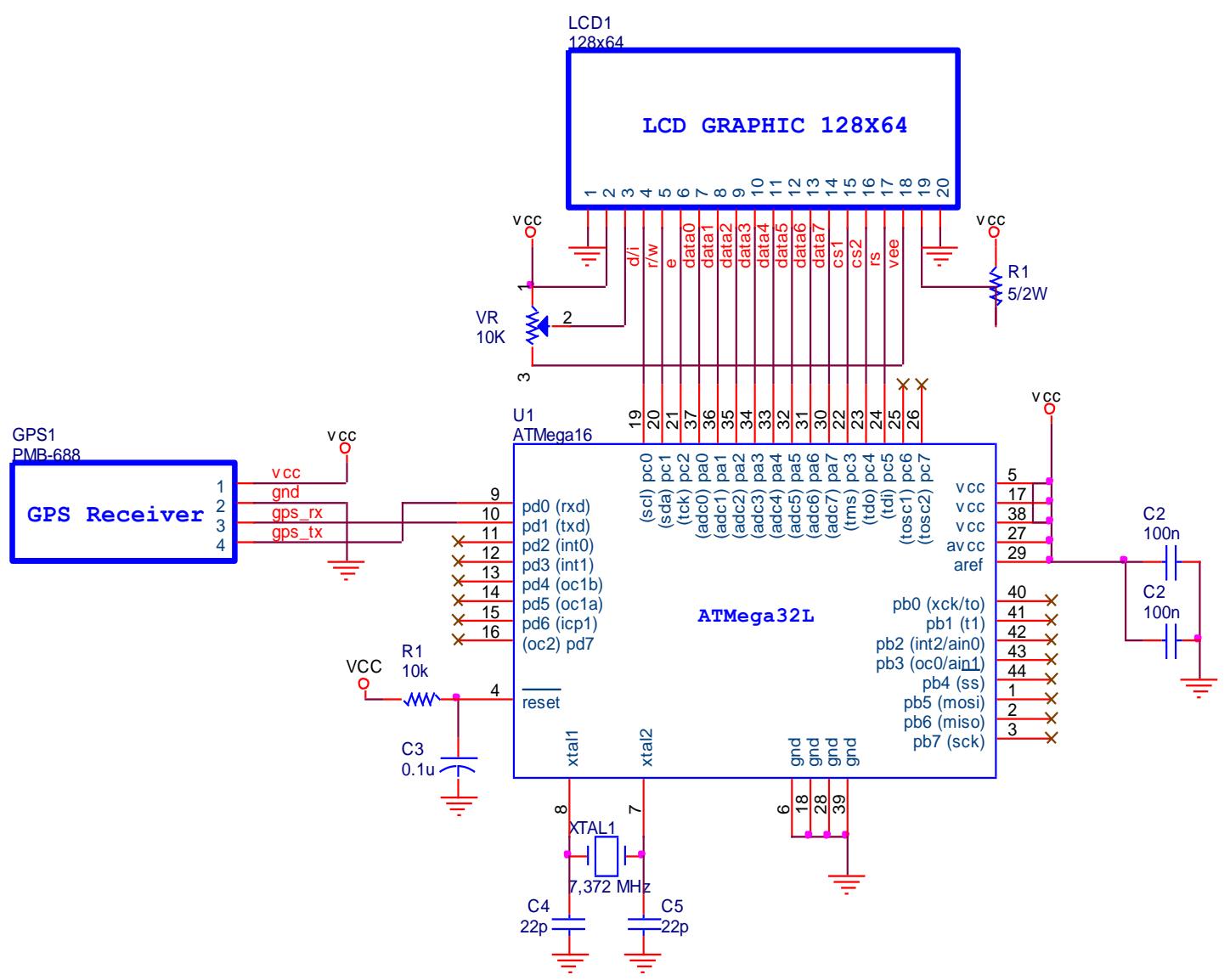

Gambar 2 Rangkaian sistem GPS portable

\section{2. 2 Perancangan Perangkat Lunak}

Perancangan perangkat lunak pada sistem GPS portable ini terdiri dari pembuatan diagram alir untuk program utama dan sub-rutin untuk membaca masukan dari modul GPS. Program pertama kali melakukan inisialisasi terhadap mikrokontroler dan LCD untuk memastikan semua komponen bekerja dan menampilkan Gambar "Hanny" yang sebelumnya sudah di konversi menjadi hanny.h. Lalu akan mengosongkan layar untuk selanjutnya digunakan untuk menampilkan data jika ada interupsi masuk seperti yang dilihat pada Gambar 3. 


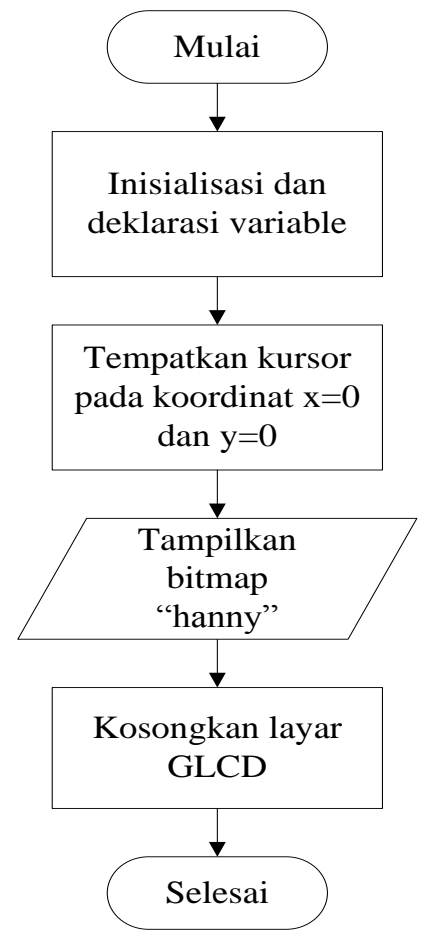

Gambar 3 Diagram alir program utama

Setelah melakukan pengosongan layar, program akan menunggu masukan dari modul GPS yang berupa interupsi serial. Pada interupsi serial ini mikrokontroler membaca masukan RMC dari GPS receiver dan dicek apakah benar data yang masuk adalah RMC. Setelah itu string RMC akan disimpan pada buffer yang selanjutnya akan dipisahkan seperti yang terlihat pada Gambar 4.

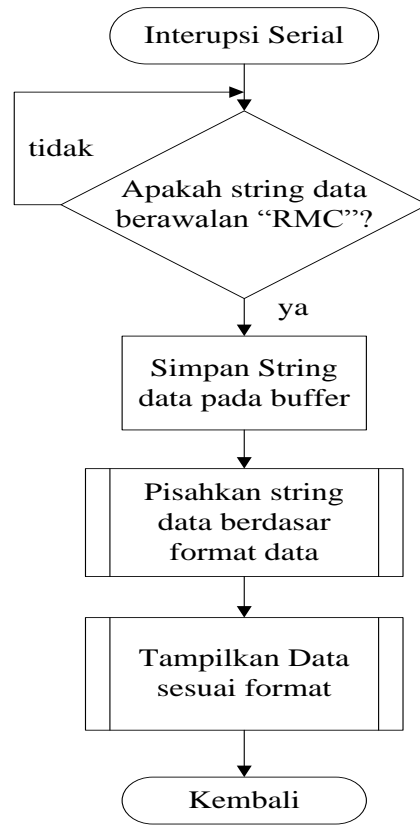

Gambar 4 Diagram alir interupsi serial.

Lalu data RMC yang berupa string tersebut akan dipisahkan sesuai format RMC. Seperti yang ditunjukkan pada Gambar 5. 


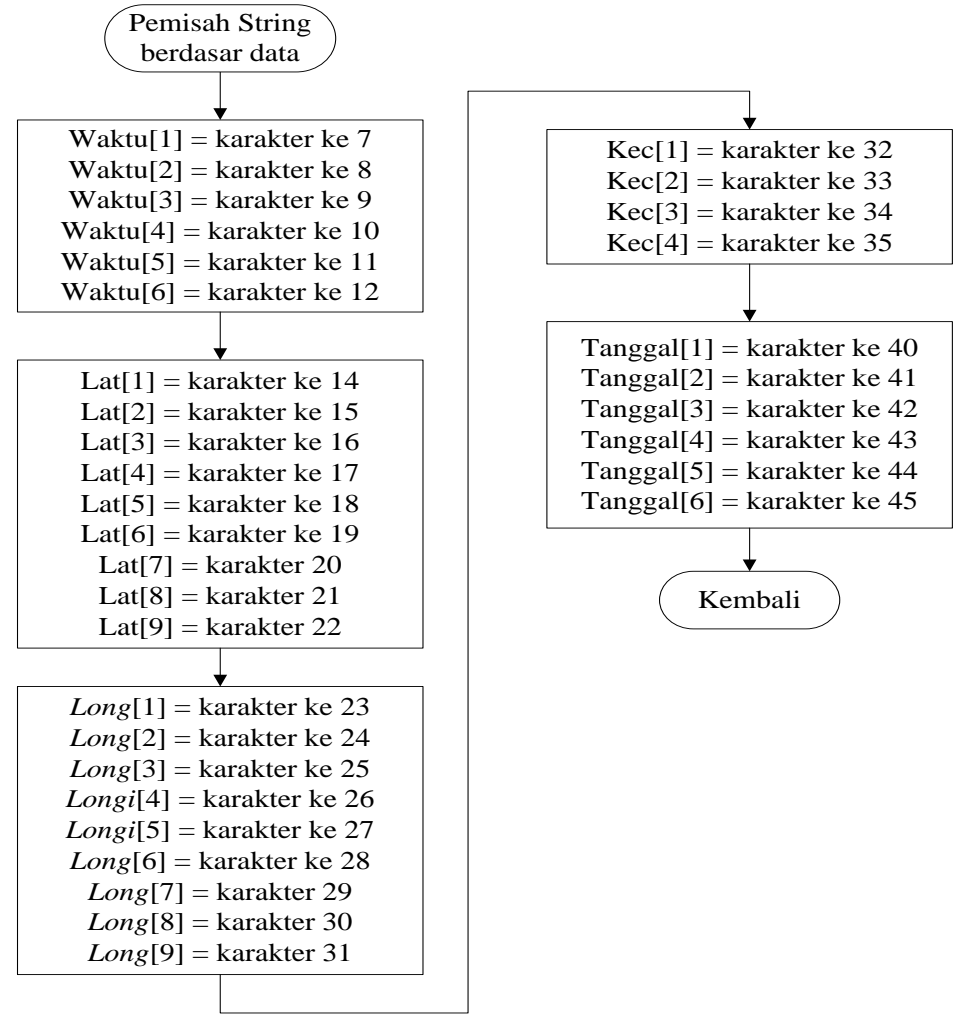

Gambar 5 Diagram alir pemisahan string RMC

Data yang sudah dipisah akan ditampilkan pada LCD. Data yang yang masuk akan dicek kevalidannya jika data tidak valid maka pada LCD akan menampilkan tulisan "data valid", jika tidak maka LCD akan menampilkan tulisan "data tidak valid".

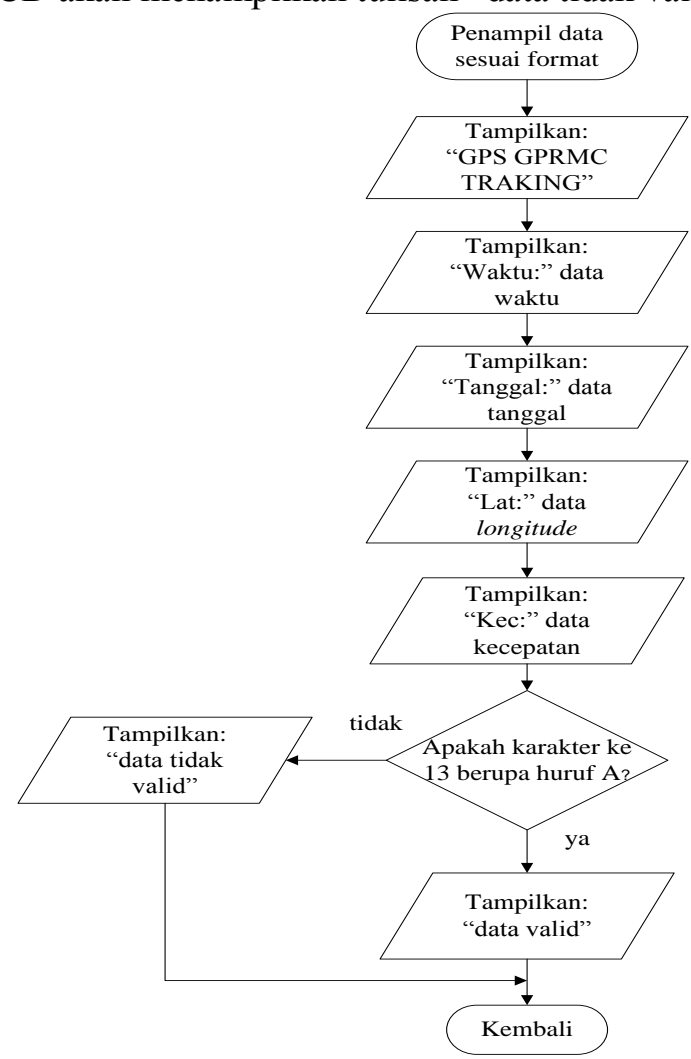

Gambar 6 Diagram alir penampil data RMC 


\section{HASIL DAN PEMBAHASAN}

Pengujian sistem GPS portable meliputi pengujian akurasi dari alat GPS portable ini dibandingkan dengan alat yang sudah terkalibrasi yaitu GPS Garmin 60Cx. Digunakan Garmin sebagai acuan dikarenakan hingga saat penelitian ini, GPS yang paling sensitive dan akurat adalah Garmin. GPS ini menggunakan chipset SiRFStarIII yang sangat sensitif.

\section{1 Pengujian Waktu dan Tanggal}

Pengujian waktu dan tanggal dilakukan pada tanggal 7 desember 2012 pukul 16:55:58 dan pukul 17.23:48 sesuai dengan waktu yang tertera pada http://time.kim.lipi.go.id/. Hasil pengujian pada pukul 16.55 ditunjukkan pada Gambar 7 .

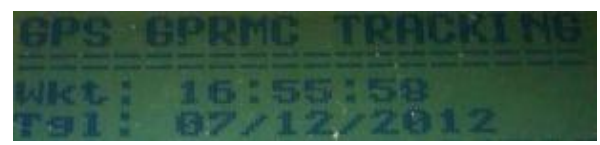

Gambar 7 Hasil pengujian pukul 16.55 Gambar 8 .

Pengujian waktu kemudian dilakukan pada pukul 17.23 yang hasilnya ditunjukan pada

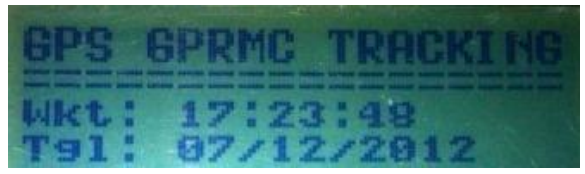

Gambar 8 Hasil pengujian pukul 17.23

Dari dua pengujian waktu yang dilakukan, dapat dilihat bahwa alat sudah menunjukkan waktu dan tanggal yang tepat. Penunjukkan waktu dan tanggal pada GPS portable ini berfungsi untuk mengetahui kapan data GPS tersebut diambil.

\section{2 Pengujian Latitude dan Longitude}

Pengujian latitude dan longitude terbagi dalam dua jenis yaitu membandingkan data bacaan koordinat dari GPS portable dengan koordinat sebuah titik referensi geodetic dan yang kedua dilakukan dengan membandingkan antara GPS portable dengan GPS Garmin 60Cx. Dalam pengujian terhadap titik referensi geodetic di depan direktorat administrasi akademik Universitas Gadjah Mada, diketahui bahwa koordinat titik referensi adalah 7,77380 lintang selatan dan 110,37679 bujur timur. Lalu dilakukan pengujian latitude dan longitude dilakukan pada tempat titik referensi geodetic tadi dan diambil datanya sebanyak 10 kali. Data pengujian di sajikan pada Tabel 2.

Tabel 2 Pengujian data latitude dan longitude terhadap titik statik

\begin{tabular}{|c|c|c|c|c|}
\hline \multirow{2}{*}{ No } & \multicolumn{2}{|c|}{ Garmin } & \multicolumn{2}{c|}{ GPS portable } \\
\cline { 2 - 5 } & Latitude & longitude & latitude & longitude \\
\hline 1 & 7,773804 & 110,376794 & 7,773791 & 110,376764 \\
\hline 2 & 7,773803 & 110,376794 & 7,773787 & 110,376754 \\
\hline 3 & 7,773803 & 110,376795 & 7,773789 & 110,376756 \\
\hline 4 & 7,773803 & 110,376794 & 7,773793 & 110,376775 \\
\hline 5 & 7,773803 & 110,376795 & 7,773792 & 110,376751 \\
\hline 6 & 7,773804 & 110,376794 & 7,773801 & 110,376789 \\
\hline 7 & 7,773803 & 110,376794 & 7,773801 & 110,376791 \\
\hline 8 & 7,773803 & 110,376794 & 7,773801 & 110,376792 \\
\hline 9 & 7,773802 & 110,376793 & 7,773804 & 110,376792 \\
\hline 10 & 7,773803 & 110,376794 & 7,773806 & 110,376791 \\
\hline
\end{tabular}


Untuk menghitung jarak antara koordinat tujuan terhadap koordinat awal, digunakan rumus:

$D=\operatorname{acos}(\sin a \times \sin b+\cos a \times \cos b \times \cos (d-c))$

Dengan a adalah nilai radian latitude titik statik, dan $\mathrm{b}$ adalah nilai radian latitude dari alat yang hendak dikalibrasi. Sedang c adalah nilai radian longitude titik statik, dan d adalah nilai radian longitude dari alat yang hendak dikalibrasi. Dan $\mathrm{R}$ sendiri adalah jari-jari bumi yang bernilai $6371009 \mathrm{~m}$. Satuan koordinat latitude dan longitude yang digunakan pada rumus perhitungan jarak ini menggunakan satuan radian. Maka sebelumnya data tersebut di konversikan menjadi radian dengan rumus sebagai berikut:

Radian $=\frac{x}{57,2957795}$

Dengan $\mathrm{x}$ adalah nilai latitude ataupun nilai longitude[6]. Didapatkan nilai radian dari titik statik adalah latitude 0,135678458 dan untuk longitude adalah 1,926438473. Lalu nilai radian hasil pengujian disajikan pada Tabel 3.

Tabel 3 Hasil konversi data latitude dan longitude dalam radian

\begin{tabular}{|c|c|c|c|c|}
\hline \multirow{2}{*}{ No } & \multicolumn{2}{|c|}{ Garmin } & \multicolumn{2}{c|}{ GPS portable } \\
\cline { 2 - 5 } & Latitude & Longitude & Latitude & Longitude \\
\hline 1 & 0,135679 & 1,926439 & 0,135678 & 1,926438 \\
\hline 2 & 0,135679 & 1,926439 & 0,135678 & 1,926438 \\
\hline 3 & 0,135679 & 1,926439 & 0,135678 & 1,926438 \\
\hline 4 & 0,135679 & 1,926439 & 0,135678 & 1,926438 \\
\hline 5 & 0,135679 & 1,926439 & 0,135678 & 1,926438 \\
\hline 6 & 0,135679 & 1,926439 & 0,135678 & 1,926438 \\
\hline 7 & 0,135679 & 1,926439 & 0,135678 & 1,926438 \\
\hline 8 & 0,135679 & 1,926439 & 0,135678 & 1,926438 \\
\hline 9 & 0,135679 & 1,926439 & 0,135679 & 1,926438 \\
\hline 10 & 0,135679 & 1,926439 & 0,135679 & 1,926438 \\
\hline
\end{tabular}

Dari data radian yang diperoleh, dihitung deviasi antara titik statik, garmin dan GPS portable. Data deviasi tersebut ditunjukkan pada Tabel 4.

Tabel 4 Data hasil perhitungan deviasi

\begin{tabular}{|c|c|c|}
\hline \multirow{2}{*}{ No } & \multicolumn{2}{|c|}{ Deviasi } \\
\cline { 2 - 3 } & $\begin{array}{c}\text { Titik Statik dan } \\
\text { Garmin }(\mathbf{m})\end{array}$ & $\begin{array}{c}\text { Titik Statik dan } \\
\text { GPS portable }(\mathbf{m})\end{array}$ \\
\hline 1 & 0,095042 & 3,567545 \\
\hline 2 & 0,000000 & 4,757781 \\
\hline 3 & 0,000000 & 4,472010 \\
\hline 4 & 0,000000 & 2,372236 \\
\hline 5 & 0,000000 & 4,899026 \\
\hline 6 & 0,095042 & 0,586876 \\
\hline 7 & 0,000000 & 0,391867 \\
\hline 8 & 0,000000 & 0,300548 \\
\hline 9 & 0,134409 & 0,232804 \\
\hline 10 & 0,000000 & 0,465607 \\
\hline $\bar{D}$ & 0,032449 & 2,204530 \\
\hline
\end{tabular}

Lalu di hitung nilai kemungkinan penyimpangan pada nilai rata-rata. Dengan menggunakan rumus deviasi standar yang merupakan cara yang sangat ampuh untuk 
menganalisa kesalahan-kesalahan acak secara statistik. Deviasi standar dari jumlah data terbatas didefinisikan sebagai akar dari penjumlahan semua penyimpangan setelah dikuadratkan dibagi dengan banyaknya pembacaan[7]. Secara sistematis dituliskan sebagai berikut:

$\sigma=\sqrt{\frac{\sum d_{t}^{2}}{n-1}}$

Dengan $d_{t}$ adalah selisih antara nilai deviasi yang di kurangkan dengan nilai deviasi rata-rata. Dan $\mathrm{n}$ adalah jumalah data pengujian. Maka didapatkan nilai error dari deviasi antara titik geodetic dengann garmin adalah $\pm 0,005059 \mathrm{~m}$. Dan untuk nilai error dari deviasi antara titik geodetic dengan GPS portable adalah $\pm 0,193001 \mathrm{~m}$.

Pengujian selanjutnya dilakukan dengan 10 titik acak untuk garmin dan GPS portable didapatkan data seperti Tabel 5 .

Tabel 5 Pengujian data latitude dan longitude titik acak

\begin{tabular}{|c|c|c|c|c|}
\hline \multirow{2}{*}{ No } & \multicolumn{2}{|c|}{ Garmin } & \multicolumn{2}{c|}{ GPS portable } \\
\cline { 2 - 5 } & Latitude & Longitude & Latitude & Longitude \\
\hline 1 & 7,773762 & 110,376757 & 7,773754 & 110,376731 \\
\hline 2 & 7,770905 & 110,377651 & 7,770932 & 110,377673 \\
\hline 3 & 7,767267 & 110,375865 & 7,767283 & 110,375872 \\
\hline 4 & 7,778205 & 110,378143 & 7,778214 & 110,378134 \\
\hline 5 & 7,779422 & 110,378272 & 7,779435 & 110,378249 \\
\hline 6 & 7,759973 & 110,380882 & 7,759967 & 110,380888 \\
\hline 7 & 7,718767 & 110,404208 & 7,718757 & 110,404203 \\
\hline 8 & 7,718323 & 110,402952 & 7,718322 & 110,402959 \\
\hline 9 & 7,718522 & 110,402945 & 7,718526 & 110,402952 \\
\hline 10 & 7,719431 & 110,401954 & 7,719435 & 110,401951 \\
\hline
\end{tabular}

Dari data yang ditunjukkan pada Tabel 5 kemudian dilakukan konversi data ke radian untuk menghitung deviasi antara garmin dan GPS portable dengan menggunakan persamaan (2). Hasil konversi dan perhitungan deviasi antara garmin dan GPS portable ditunjukkan pada Tabel 6.

Tabel 6 Hasil konversi radian dan perhitungan deviasi

\begin{tabular}{|c|c|c|c|c|c|}
\hline \multirow{2}{*}{ No } & \multicolumn{2}{|c|}{ Garmin } & \multicolumn{2}{|c|}{ GPS portable } & \multirow{2}{*}{$\begin{array}{c}\text { Deviasi } \\
\text { (m) }\end{array}$} \\
\hline & Latitude & Longitude & Latitude & Longitude & \\
\hline 1 & 0,135678 & 1,926438 & 0,135678 & 1,926437 & 3,002474 \\
\hline 2 & 0,135628 & 1,926453 & 0,135628 & 1,926454 & 3,864118 \\
\hline 3 & 0,135564 & 1,92 & 0,135565 & 1,926422 & \\
\hline 4 & & & & & \\
\hline 5 & 0,1 & & 5777 & & \\
\hline 6 & 0 , & & 437 & 10 & 52 \\
\hline 7 & 718 & 17 & 0,134718 & 917 & 191 \\
\hline 8 & 710 & & 0,134710 & 6895 & 0,777949 \\
\hline 9 & 0,134714 & 895 & 0,134714 & 1,926895 & 0,891570 \\
\hline 10 & 0,134729 & 1,926878 & 0,134730 & 1,926878 & 0,554183 \\
\hline & & & & $\overline{\bar{D}}$ & 1,753449 \\
\hline
\end{tabular}

Dan kembali dihitung nilai kemungkinan penyimpangan pada nilai rata-rata. Dengan menggunakan rumus (3). Didapatkan nilai penyimpangan $\pm 0,113532 \mathrm{~m}$. 
Dari data pada table 6 dapat dihitung deviasi rata-rata antara garmin dan GPS portable yaitu $1,753449 \mathrm{~m} \pm 0,113532 \mathrm{~m}$. Nilai ini lebih kecil dari yang terdapat di datasheet. Sehingga GPS ini bekerja dengan baik dan dapat dikatakan akurat. Dikarenakan dalam radius deviasi tersebut manusia masih dapat melihat tujuannya.

Faktor-faktor yang dapat menurunkan sinyal GPS dan mempengaruhi akurasi adalah sebagai berikut[8]:

a. Penundaan dari ionosfer dan troposfer

Sinyal satelit melambat saat melewati atmosfer. Sistem GPS terbaru sudah menggunakan model yang sudah terpasang yang menghitung jumlah rata-rata keterlambatan dan mengkoreksi kesalahan.

b. Sinyal multipath

Terjadi ketika sinyal GPS ini tercermin dari objek seperti gedung-gedung tinggi atau permukaan batu besar sebelum mencapai penerima. Hal ini akan meningkatkan waktu perjalanan sinyal, sehingga menyebabkan kesalahan.

c. Kesalahan jam receiver

Sebuah receiver dengan jam built-in tidak seakurat jam-jam atom pada satelit GPS onboard. Karena itu, mungkin ada kesalahan sedikit pada waktu.

d. Kesalahan orbital

Juga dikenal sebagai kesalahan ephemeris, ini adalah ketidakakuratan dari satelit melaporkan lokasi.

e. Jumlah satelit terlihat

Semakin banyak satelit yang dapat dilihat oleh GPS akurasi yang lebih baik. Bangunan, bentuk suatu permukaan, interferensi elektronik, atau bahkan kadang-kadang dedaunan yang lebat dapat memblokir penerimaan sinyal, menyebabkan kesalahan posisi atau mungkin tidak membaca posisi sama sekali. Unit GPS biasanya tidak akan bekerja dalam ruangan, bawah laut atau bawah tanah.

f. Geometri satelit (shading)

mengacu pada posisi reltif satelit pada suatu waktu. Geometri satelit ideal terjadi ketika satelit berada di sudut lebar relatif terhadap satu sama lain. Hasil geometri yang tidak bagus saat satelit berada dalam satu garis atau dalam kelompok satelit yang berdekatan.

g. Degradasi dari sinyal satelit yang disengaja

Selective Availability (SA) adalah kesengajaan degradasi sinyal oleh Departemen Pertahanan Amerika Serikat. SA dimaksudkan untuk mencegah musuh militer dari menggunakan GPS yang sangat akurat. SA dinonaktifkan oleh pemerintah AS pada bulan Mei 2000, yang secara signifikan meningkatkan akurasi penerima GPS sipil.

\section{3 Pengujian Kecepatan}

Pengujian kecepatan ini dengan cara mengendarai motor dengan kecepatan tertentu dan dilihat nilai yang ada pada GPS portable kemudian dibandingkan dengan kecepatan pada Garmin dan kecepatan motor tersebut. Dari hasil pengujian kecepatan didapatkan data yang ditunjukkan pada Tabel 7.

Tabel 7 Data pengujian kecepatan dan selisihnya

\begin{tabular}{|c|c|c|c|c|c|c|}
\hline \multirow{2}{*}{ No } & \multicolumn{3}{|c|}{ Kecepatan (km/j) } & \multicolumn{3}{c|}{ Selisih $(\mathbf{k m} / \mathbf{j})$} \\
\cline { 2 - 7 } & P. GPS & Garmin & Motor & $\begin{array}{c}\text { P.GPS } \\
\text { dan motor }\end{array}$ & $\begin{array}{c}\text { Garmin } \\
\text { dan motor }\end{array}$ & $\begin{array}{c}\text { P.GPS } \\
\text { dan Garmin }\end{array}$ \\
\hline 1 & 20,456 & 20,030 & 20,000 & 0,456 & 0,030 & 0,426 \\
\hline 2 & 29,589 & 30,110 & 30,000 & 0,411 & 0,110 & 0,521 \\
\hline 3 & 39,267 & 39,870 & 40,000 & 0,733 & 0,130 & 0,603 \\
\hline 4 & 50,541 & 49,920 & 50,000 & 0,541 & 0,080 & 0,621 \\
\hline 5 & 60,054 & 60,020 & 60,000 & 0,054 & 0,020 & 0,034 \\
\hline \multicolumn{3}{|c|}{$\overline{\Delta v}$} & 0,439 & 0,074 & 0,441 \\
\hline
\end{tabular}

IJEIS Vol. 3, No. 1, April 2013 : $105-116$ 
Kemudian dihitung nilai kemungkinan penyimpangan pada nilai rata-rata. Dengan menggunakan rumus (3), didapatkan nilai penyimpangan untuk selisih kecepatan GPS portable dengan motor adalah $\pm 0,248 \mathrm{~km} / \mathrm{j}$. Untuk selisih kecepatan Garmin dengan motor adalah \pm $0,049 \mathrm{~km} / \mathrm{j}$. Dan untuk selisih kecepatan garmin dan GPS portable adalah $\pm 0,247 \mathrm{~km} / \mathrm{j}$.

Dari data yang ditunjukkan pada Tabel 6.6 terdapat perbedaan hasil yang ditunjukkan oleh GPS portable dan kecepatan pada spedometer. Rata-rata selisih antara motor dan GPS portable adalah $0,439 \mathrm{~km} / \mathrm{j} \pm 0,248 \mathrm{~km} / \mathrm{j}$, sedangkan rata-rata selisih garmin dengan motor adalah $0,074 \mathrm{~km} / \mathrm{j} \pm 0,049 \mathrm{~km} / \mathrm{j}$. Bisa dikatakan nilai selisih pada garmin mendekati 0 sehingga bisa digunakan untuk standarisasi. Jika garmin dibandingkan dengan GPS portable, maka selisih yang di dapatkan $0,441 \mathrm{~km} / \mathrm{j} \pm 0,247 \mathrm{~km} / \mathrm{j}$. Nilai tersebut kecil sehingga bisa dikatakan bahwa penunjukkan kecepatan pada alat GPS portable ini akurat.

\section{KESIMPULAN}

Setelah melakukan penelitian dan pengujian, maka dapat diambil beberapa kesimpulan, yaitu:

1. Sistem GPS portable telah berjalan dengan baik.

2. Sistem GPS portable mampu menampilkan waktu, latitude, longitude, kecepatan dan kevalidan data.

3. Deviasi rata-rata GPS portable untuk data latitude dan longitude adalah 1,753449 $\pm 0,113532 \mathrm{~m}$ lebih kecil dari yang tertera pada datasheet yaitu $5 \mathrm{~m}$.

4. Deviasi rata-rata GPS portable untuk data kecepatan adalah $0,441 \mathrm{~km} / \mathrm{j} \pm 0,247$ $\mathrm{km} / \mathrm{j}$ lebih kecil dari yang tertera pada datasheet yaitu $3,6 \mathrm{~km} / \mathrm{j}$.

5. Adanya kesalahan akurasi GPS disebabkan karena adanya penundaan dari ionosfer dan troposfer, sinyal multipath, kesalahan jam receiver, kesalahan orbital, jumlah satelit terlihat, geometri satelit (shading), dan degradasi dari sinyal satelit yang disengaja.

\section{DAFTAR PUSTAKA}

[1] Prahasta, Eddy, 2002, Konsep-konsep Dasar Sistem Informasi Geografis, Informatika, Bandung.

[2] Polstar, 2010, PMB-688_Brochure_V0.2, Tersedia di www.polstargps.com/Support/Spec/PMB-688_Brochure_V0.2.pdf diakses pada 3 september 2012.

[3] Betke, Klause, 2000, The NMEA 0183 Protocol, NewBern. USA. Tersedia di www.tronico.fi/OH6NT/docs/NMEA0183.pdf diakses pada 17 oktober 2012.

[4] Atmel, 2012, ATmega32/L Datasheet, Tersedia di www.atmel.com/Images/doc2503.pdf diakses pada 3 september 2012.

[5] Topway Technologies, 2004, LM12864LFC LCD Module User Manual, Tersedia di www.ic72.com/pdf/download.html?id=9183 diakses pada 3 desember 2012.

[6] Abidin, HZ, dkk, 2001, Survei Dengan GPS, Pranya Pharamita, Jakarta. 
[7] Hvistendahl, H.S., 1964, Engineering Units and Physical Quantitites, MacMillan and Co, London.

[8] Parkinson, B.W., 1996. Global Positioning System: Theory and Applications, American Institute of Aeronautics and Astronautics, Washington, D.C. 